\title{
Degradation of thiamethoxam wastewater using the gas diffusion electrode catalyst by $\mathrm{LaNi}_{1-\mathrm{x}} \mathrm{Co}_{\mathrm{x}} \mathrm{O}_{3}$
}

\author{
Shanping $\mathrm{Li}^{\mathrm{a}, \mathrm{b}}$, Lijun $\mathrm{Liu}^{\mathrm{a}}$, Yahui $\mathrm{Li}^{\mathrm{a}}$
}

\begin{abstract}
a.School of Environmental Science and Engineering, Shandong University, 27 Shandananlu, Jinan , 250100,China.

b.Shandong Key Laboratory of Water Pollution Control and Resource Reuse, Jinan, 250100, China E-mail: lishanping@sdu.edu.cn
\end{abstract}

Corresponding author. Professor Shanping Li Tel.:+86 0531-88362872; fax: +86 0531-88362872

Keywords: $\mathrm{LaNi}_{1-\mathrm{x}} \mathrm{Co}_{\mathrm{x}} \mathrm{O}_{3}$; perovskite; gas diffusion electrode; thiamethoxam; degradation

Abstract. Cobalt doped at $\mathrm{B}$ site from $\mathrm{LaNiO}_{3}$ with catalyst perovskite structure was synthesized by sol-gal process of thermal decomposition citrates. The gas diffusion electrode was manufactured via a complex process chain of catalyst $\mathrm{LaNi}_{1-\mathrm{x}} \mathrm{Co}_{\mathrm{x}} \mathrm{O}_{3}(\mathrm{LNC}, \mathrm{x}=0,0.2,0.4,0.8,1.0)$, graphite, sodium sulfate, PTFE and acetylene black. TGA-DTA, X-ray diffraction (XRD) and transmission electron microscope (TEM) were performed to investigate sintering temperature and crystal structure of $\mathrm{LaNi}_{1-\mathrm{x}} \mathrm{Co}_{\mathrm{x}} \mathrm{O}_{3}$. Meanwhile, the electrode characteristic was investigated by using cyclic voltammetry $(\mathrm{CV})$ and degradation experiment. The results suggested excellent electrochemical characteristics of gas diffusion electrode equipped with perovskite-type oxide of $\mathrm{LaNi}_{0.8} \mathrm{Co}_{0.2} \mathrm{O}_{3}$ with respect to the oxygen reduction reaction. Good degradation of thiamethoxam pesticide wastewater concentration was also observed by UV-vis spectrophotometer equipment. Specifically, after 60 minutes of electrochemical catalytic degradation in Electro-Fenton Oxidation Process, the maximum degradation efficiency could be reached with the current density $3.1 \mathrm{~mA} / \mathrm{cm}^{2}$, and $\mathrm{pH} 3$. It was worth noting that both the current density and $\mathrm{pH}$ met the first order reaction kinetics equation in the degradation process. In addition, an improved gas diffusion electrode was manufactured so as to analyze the products (N-methyl-nitro-formamide) of thiamethoxamin degradation process by LCMS. The results demonstrated improved degradation efficiency of refractory organics with the method.

\section{Introduction}

Neonicotinoid pesticides have been extensively used currently, which occupies nearly $25 \%$ of the global insecticide market. Among them, the compound thiamethoxam (TMX) is widely employed[1,2], leading to more and more thiamethoxam released into the environment, such as the area of foliage, seed and stem treatment etc[3-5]. As a result, its massive accumulation in the environment will greatly threaten human health if not be treated as early as possible.

Advanced oxidation processes (AOPs) are promising techniques for remediation of contaminated water by in-situ destruction and mineralization of non-biodegradable organics[6, 7], which can generate active free radicals $($ e.g. $\bullet O H)$ that oxidize many organic contaminants [8] for the treatment of refractory organic wastewater from chemical, dyeing and printing, pharmaceutical, pesticides and oil industries. Over the past few decades, AOPs including chemical oxidation process[9], photochemical oxidation process[10], wet oxidation process[11], supercritical water oxidation process (SCWO) [12], etc. used for the degradation of pesticides have not been found effective for this purpose but had lots of disadvantages, such as secondary pollution, high operative costs, long reaction time and poor maneuverability. However, among the AOPs, Electro-Fenton (EF) Oxidation Process is particularly attractive because of its highly-efficiency, amenability to automation, and environmental compatibility[13]. The key factor that influences degradation efficiency is the production of hydroxyl radicals $(\bullet \mathrm{OH})$. In Fenton oxidation process, $\mathrm{H}_{2} \mathrm{O}_{2}$ reacts with $\mathrm{Fe}^{2+}$, thereby generating hydroxyl radicals and ferric ion according to Eq. 1[14]. The hydroxyl radicals can oxidize large molecules into smaller ones so that their toxicity is less than the mother substance. 


$$
\mathrm{H}_{2} \mathrm{O}_{2}+\mathrm{Fe}^{2+}+\mathrm{H}^{+} \longrightarrow \mathrm{Fe}^{3+}+\cdot \mathrm{OH}+\mathrm{H}_{2} \mathrm{O}
$$

In this study, we employ EF Oxidation Process, in which Fenton's reagent is utilized to produce hydroxyl radical in the electrolytic cell and ferrous ion is regenerated via the reduction of ferric ion on the cathode[15]. One of the key means to improve the degradation efficiency of EF Oxidation Process is selecting the working electrode materials. It is well known that perovskite type oxides $\left(\mathrm{ABO}_{3}\right)$ have attracted worldwide interests due to their excellent properties of catalytic combustion, electrode materials[16], etc. The characteristics of A and B ions and their valence states greatly affect the catalytic characteristics of perovskite-type oxides and the stabilities of the perovskite phases. Perovskite structures allow replacement of partial A or B cations with heterovalent elements, inducing oxygen vacancies or variation of valence state of $A / B$-sites.

In addition, some studies have demonstrated that partial substitution of B cation could improve the perovskite catalysts activity[17]. Specifically, transition metals additives could improve the performance of perovskite type oxides catalyst[18, 19]. Among these perovskite catalysts, lanthanum nickel oxide $\mathrm{LaNiO}_{3}$ has been widely used because of its good electronic and catalytic features. For instance, it was employed as the fundamental material of electrode for propene and $\mathrm{CO}$ combustion reactions[20], as well as catalyst for the degradation of wastewate[21]. A number of works have been carried out in order to improve $\mathrm{LaNiO}_{3}$ activity by partial substitution of $\mathrm{B}$. Meanwhile, $\mathrm{LaNi}_{1-\mathrm{x}} \mathrm{Co}_{\mathrm{x}} \mathrm{O}_{3}$ is known as an electrode catalyst material due to its high catalytic activity for fuel cell[22], dry reforming of methane[23], deep oxidation of propane[24], etc.

However, there are few studies reporting degradation of thiamethoxam pesticide wastewater with $\mathrm{LaNi}_{1-\mathrm{x}} \mathrm{Co}_{\mathrm{x}} \mathrm{O}_{3}$ as the catalyst. This paper investigated degradation of thiamethoxam pesticide wastewater using the perovskite-type oxide $\mathrm{LaNi}_{0.8} \mathrm{Co}_{0.2} \mathrm{O}_{3}$ as the cathode catalyst applied to the EF Oxidation Process. In this paper, TGA/DTA, XRD and TEM were performed to study the properties of $\mathrm{LaNi}_{1-\mathrm{x}} \mathrm{Co}_{\mathrm{x}} \mathrm{O}_{3}$. Meanwhile, the characteristics of gas diffusion electrode were researched by using cyclic voltammetry analysis and tested for thiamethoxam degradation. The effects of current density, $\mathrm{pH}$ and degradation time upon the thiamethoxam removal efficiency were investigated.

\section{Material and Methods}

\section{Preparation of $\mathrm{LaNi}_{0.8} \mathrm{Co}_{0.2} \mathrm{O}_{3}$}

$\mathrm{LaNi}_{0.8} \mathrm{Co}_{0.2} \mathrm{O}_{3}$ was synthesized by the sol-gel method based on previous works[25]. A given amount of analytical-grade Lanthanum nitrate hexahydrate $\left(\mathrm{La}\left(\mathrm{NO}_{3}\right)_{3} \cdot 6 \mathrm{H}_{2} \mathrm{O}\right.$, purchased from Beijing FangZheng Rare Earth of Science and Technology Research Institute Co., Ltd.), Nickel nitrate hexahydrate $\left(\mathrm{Ni}\left(\mathrm{NO}_{3}\right)_{3} \cdot 6 \mathrm{H}_{2} \mathrm{O}\right.$, purchased from Tianjin Guangcheng Chemical Industry Co., Ltd.), Cobalt nitrate hexahydrate $\left(\mathrm{Co}\left(\mathrm{NO}_{3}\right)_{3} \bullet 6 \mathrm{H}_{2} \mathrm{O}\right.$, purchased from Tianjin DaMao Chemical Reagent Factory) and citric acid $\left(\mathrm{C}_{6} \mathrm{H}_{8} \mathrm{O}_{7} \cdot \mathrm{H}_{2} \mathrm{O}\right.$, purchased from Tianjin Guangcheng Chemical Industry Co., Ltd.) were diluted with alcohol to $100 \mathrm{~mL}$. The molar ratio of citric acid and metal molar were set to 1.5 . Then, $\mathrm{NH}_{3} \cdot \mathrm{H}_{2} \mathrm{O}$ was added so as to adjust the $\mathrm{pH}$ value to 10 and to obtain transparent solution, which was heated in $80{ }^{\circ} \mathrm{C}$ water-bath until turning into a gel. The compound was then calcined at $800{ }^{\circ} \mathrm{C}$ for $2 \mathrm{~h}$ with a rate of $10{ }^{\circ} \mathrm{C} / \mathrm{min}$ under air atmosphere.

\section{Preparation of gas-diffusion cathode}

To prepare $\mathrm{LNC}$ gas-diffusion electrode, $\mathrm{LaNi}_{1-\mathrm{x}} \mathrm{Co}_{\mathrm{x}} \mathrm{O}_{3}$ powder, graphite, acetylene black, $\mathrm{Na}_{2} \mathrm{SO}_{4}$, and PTFE were dispersed in anhydrous ethanol with sonication for $2 \mathrm{~h}$. A uniform suspension could be obtained, which was then heated at $80{ }^{\circ} \mathrm{C}$ in a water bath until a thick paste was produced. Divided into two parts, the paste was smeared on both sides of nickel foam, and pressed under $15 \mathrm{MPa}$ for $30 \mathrm{~min}$, and heated at $350{ }^{\circ} \mathrm{C}$ for $2 \mathrm{~h}$ with a rate of $5{ }^{\circ} \mathrm{C} / \mathrm{min}$ under air atmosphere. Thus, the gas-diffusion electrode $(5.1 \mathrm{~cm} \times 3.2 \mathrm{~cm})$ consisted of $2.9 \mathrm{wt} . \% \mathrm{LaNi}_{1-\mathrm{x}} \mathrm{Co}_{\mathrm{x}} \mathrm{O}_{3}, 52.6 \mathrm{wt} . \%$ graphite, 5.8 wt.\% AB, 9.7 wt.\% $\mathrm{Na}_{2} \mathrm{SO}_{4}$ and 29 wt.\% PTFE.

\section{Characterization of catalyst}

Thermo-gravimetric and differential thermal analysis (TGA/DTA) was performed with Q600SPT analyzer in a flow of air from room temperature up to $800{ }^{\circ} \mathrm{C}$ at a heating rate of $10{ }^{\circ} \mathrm{C} / \mathrm{min}$ in an $\mathrm{Al}_{2} \mathrm{O}_{3}$ sample pan. XRD of $\mathrm{LaNi}_{1-\mathrm{x}} \mathrm{Co}_{\mathrm{x}} \mathrm{O}_{3}$ was conducted with a diffractometer (Rigaku D/MAX- 
rA) with $\mathrm{Cu} \mathrm{K}-\alpha$ radiation $(\lambda=0.154184 \AA)$. The $2 \theta$ ranges from $0^{\circ} \sim 70^{\circ}$, and the scan rate is $8^{\circ} / \mathrm{min}$. The transmission electron microscopy was done using a JEOL JEM 2010F equipped with a field emission gun operated at $200 \mathrm{kV}$. The domain sizes and morphology were observed by TEM with magnification of 72000 times.

\section{Degradation system of thiamethoxam}

The steps of using self-designed gas diffusion electrode in electrochemical principles to degrade thiamethoxam pesticide wastewater are as below:

(1) $(1 \mathrm{~L})$ thiamethoxam solution of $10 \mathrm{mg} / \mathrm{L},(7.062 \mathrm{~g})$ sodium sulfate as electrolyte, $(0.278 \mathrm{~g})$ ferrous sulfate as the catalyst of electrical Fenton reaction were added into an electrolyzer, and stirred for 30 40 min with the magnetic stirring apparatus. Meanwhile, the solution $\mathrm{pH}$ was adjusted to $\mathrm{pH} 3$.

(2) The distance between the self-designed gas diffusion electrode including acetylene black and LNC catalyst (cathode) and the ordinary graphite electrode (anode) is $3 \mathrm{~cm}$, and an external DC power source provides the current density of $3.1 \mathrm{~mA} / \mathrm{cm}^{2}$. Aeration was performed for $30 \mathrm{~min}$ at the speed of $10 \mathrm{~L} / \mathrm{min}$ in the electrolyzer, which was stirred for 10 20 min with the magnetic stirring apparatus.

The synthetic wastewater was prepared in the supporting electrolyte of $\mathrm{Na}_{2} \mathrm{SO}_{4}$, whose $\mathrm{pH}$ was adjusted with proper $\mathrm{H}_{2} \mathrm{SO}_{4}$ or $\mathrm{NaOH}$. Meanwhile, oxygen was supplied with a gas flowmeter near the cathode at a certain flow rate. Additionally, $\mathrm{FeSO}_{4}$ was added into the solution and kept stable electrochemical potential via constant voltage[26].

\section{Electrochemical measurements}

Electrochemical parameters of preparing LNC gas-diffusion electrodes were measured with cyclic voltammetry method at an electrochemical workstation (CHI700B, ChenHua, Shanghai, China). A standard three-electrode electrochemical system was adopted in the measurement, where cathode catalyst, saturated calomel electrode and ordinary graphite electrode were used as working electrode, reference electrode and counter electrode, respectively[27].

Thiamethoxam concentration was determined on UV-vis spectrophotometer equipment at $\lambda=250 \mathrm{~nm}$ (TU-1810). The degradation efficiency $(\eta)$ is obtained by the following Eq. 2 :

$$
\eta=\frac{A_{0}-A_{\mathrm{t}}}{A_{0}} \times 100 \%
$$

Where $\mathrm{A}_{0}$ and $\mathrm{A}_{\mathrm{t}}$ are the absorbency at initial time and " $\mathrm{t}$ " moment, respectively.

\section{Results and Discussions}

\section{Effect of sintering temperature on perovskite catalyst}

Decomposition processes of xerogel perovskite catalyst at different temperatures were observed through the TGA/DTA curve (Fig. 1). The stage 1 transformation completed at $252{ }^{\circ} \mathrm{C}$, showing a slow mass loss of $22.82 \%$ for preheated perovskite catalyst sample, in correlation with a small endothermic peak. This mainly corresponds most likely to dissipation of xerogel residual water or hydrated water that may remain in the perovskite catalyst sample, in agreement with previous reports[28, 29]. The stage 2 transformation completed at $380{ }^{\circ} \mathrm{C}$, showing an obvious mass loss of $31.51 \%$ for in-depth heating of perovskite catalyst sample, which might be due to steam and carbon dioxide resulted from combustion of citric acid, in coincidence with observation of the relatively broad exothermic peaks. The stage 3 transformation completed at $524{ }^{\circ} \mathrm{C}$, there was few mass loss $(9.9 \%)$, because of decomposition of the remaining nitrate and citric acid complexes probability. The last stage completed at $800{ }^{\circ} \mathrm{C}$ nearly without any mass loss, indicating that the compound formed at $800{ }^{\circ} \mathrm{C}$ was in a stable state, besides, there was a weak exothermic peak in the DTA curve when calcination temperature was closed to $800{ }^{\circ} \mathrm{C}$, which may be the optimal temperature for perovskite formation, in agreement with TEM results discussed below. 


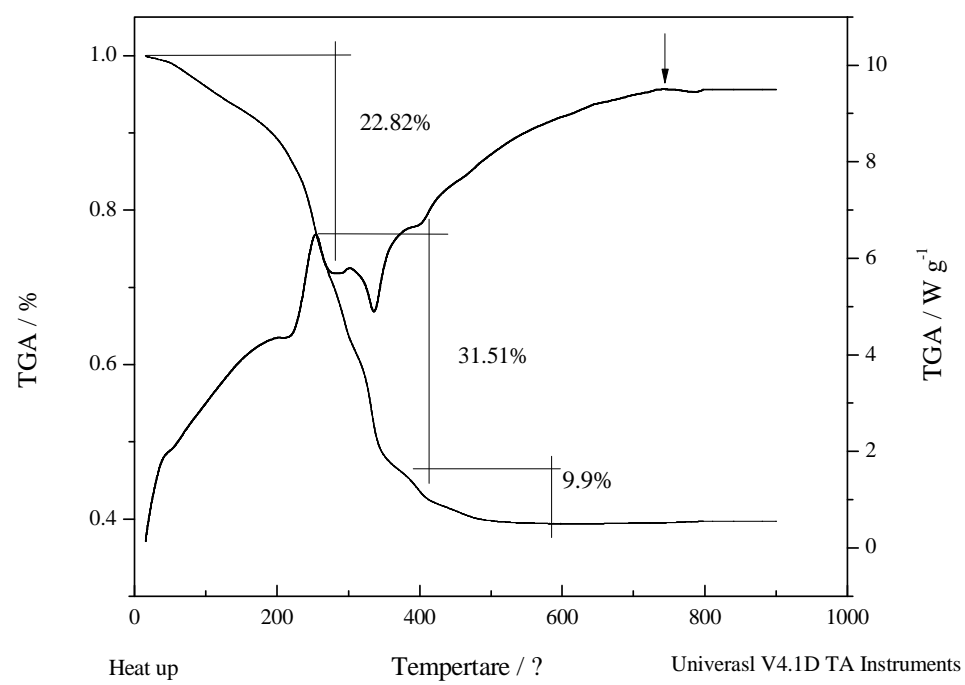

Fig. 1 TGA/DTA analysis of perovskite catalyst

\section{Characterization of $\mathrm{LaNi}_{1-\mathrm{x}} \mathrm{Co}_{\mathrm{x}} \mathrm{O}_{3}$}

Fig. 2 shows the XRD profiles of the $\mathrm{LaNi}_{1-\mathrm{x}} \mathrm{Co}_{\mathrm{x}} \mathrm{O}_{3}(\mathrm{x}=0,0.2,0.4,0.8,1.0)$ perovskites annealed at $800{ }^{\circ} \mathrm{C}$. The XRD patterns are in good agreement with that of perovskite-type $\mathrm{La}_{1-\mathrm{x}} \mathrm{Ce}_{\mathrm{x}} \mathrm{MnO}_{3}$ reported in previous literature[30].

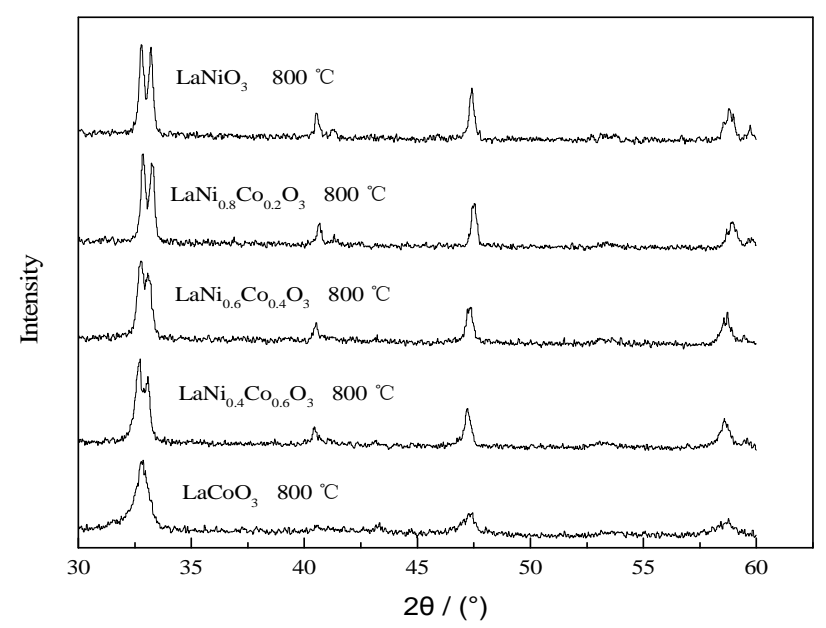

According to Bragg's law:

Fig. 2 XRD patterns of $\mathrm{LaNi}_{1-\mathrm{x}} \mathrm{Co}_{\mathrm{x}} \mathrm{O}_{3}$

$$
\mathrm{d}=\mathrm{n} \lambda / 2 \sin \theta
$$

Where $\mathrm{n}$ is an integer determined by the order given, and $\lambda$ is the wavelength $(\lambda=0.154184 \mathrm{~nm})$. $\mathrm{d}$ is the spacing between the planes in the atomic lattice, and $\theta$ is the angle between the incident ray and the scattering planes. The parameter $\mathrm{d}$ of different ratio perovskite catalyst was calculated so as to compare with the standard lattice parameters of $\mathrm{LaNiO}_{3}$. The results are shown in Table 1:

Table 1 Comparison of LNC lattice parameters

\begin{tabular}{cccccc}
\hline $\begin{array}{c}\text { lattice plane } \\
\text { catalyst }\end{array}$ & 101 & 110 & 021 & 202 & 122 \\
\hline $\mathrm{LaNiO}_{3}$ & 3.860 & 2.745 & 2.218 & 1.924 & 1.574 \\
$\mathrm{LaNi}_{0.8} \mathrm{Co}_{0.2} \mathrm{O}_{3}$ & 3.839 & 2.710 & 2.221 & 1.918 & 1.569 \\
$\mathrm{LaNi}_{0.6} \mathrm{Co}_{0.4} \mathrm{O}_{3}$ & 3.837 & 2.704 & 2.219 & 1.917 & 1.571 \\
$\mathrm{LaNi}_{0.2} \mathrm{Co}_{0.8} \mathrm{O}_{3}$ & 3.835 & 2.752 & 2.220 & 1.915 & 1.570 \\
$\mathrm{LaCoO}_{3}$ & 3.831 & 2.706 & 2.216 & 1.916 & 1.565 \\
$\begin{array}{c}\mathrm{LaNiO} \\
\text { (Theoretically) }\end{array}$ & 3.840 & 2.728 & 2.223 & 1.919 & 1.575 \\
\hline
\end{tabular}

As known from the simulation results, lattice parameters of perovskite catalyst of different 
ratio were within the allowable theoretical range, also suggesting that five prepared groups of catalysts $\left(\mathrm{LaNi}_{1-\mathrm{x}} \mathrm{Co}_{\mathrm{x}} \mathrm{O}_{3}\right)$ have the perovskite structure.

According to Scherer formula:

$$
\mathrm{D}=\mathrm{k} \lambda / \beta \cos \theta
$$

where $\mathrm{D}$ is the mean size of the ordered (crystalline) domains, which may be smaller or equal to the grain size; $\mathrm{k}$ is a dimensionless shape factor (0.89), with a value close to unity. $\lambda$ is the $\mathrm{X}$-ray wavelength (0.154184); $\beta$ is the line broadening at half the maximum intensity (FWHM), after subtracting the instrumental line broadening, in radians. $\theta$ is the Bragg angle. The domain sizes of lattice plane (110) were calculated as shown in Table 2

Table 2 Crystal domain sizes of lattice plane (110) (nm)

\begin{tabular}{|c|c|c|c|c|c|}
\hline $\begin{array}{c}\text { perovskite } \\
\text { catalyst }\end{array}$ & $\begin{array}{c}\mathrm{LaNi} \\
\mathrm{O}_{3}\end{array}$ & $\begin{array}{c}\mathrm{LaNi}_{0.8} \mathrm{Co}_{0.2} \\
\mathrm{O}_{3}\end{array}$ & $\begin{array}{c}\mathrm{LaNi}_{0.6} \mathrm{Co}_{0.4} \\
\mathrm{O}_{3}\end{array}$ & $\begin{array}{c}\mathrm{LaNi}_{0.2} \mathrm{Co}_{0.8} \\
\mathrm{O}_{3}\end{array}$ & $\begin{array}{c}\mathrm{LaCo} \\
\mathrm{O}_{3}\end{array}$ \\
\hline $\mathrm{D}(110)$ & 25.08 & 24.26 & 16.06 & 18.81 & 19.88 \\
\hline
\end{tabular}

It can be observed the presence of crystal domain sizes with an average diameter around 16 25 $\mathrm{nm}$, most of which were synthesized to the perovskite catalyst of nanoscale level.

In order to investigate the influence of calcination temperature on properties like domain size and degree of dispersion of $\mathrm{LaNi}_{1-\mathrm{x}} \mathrm{Co}_{\mathrm{x}} \mathrm{O}_{3}$ catalyst, TEM characterization of LNC catalyst was performed under different calcinations temperature with a magnification of 72000 times. The particle distribution is as shown in Fig. 3.

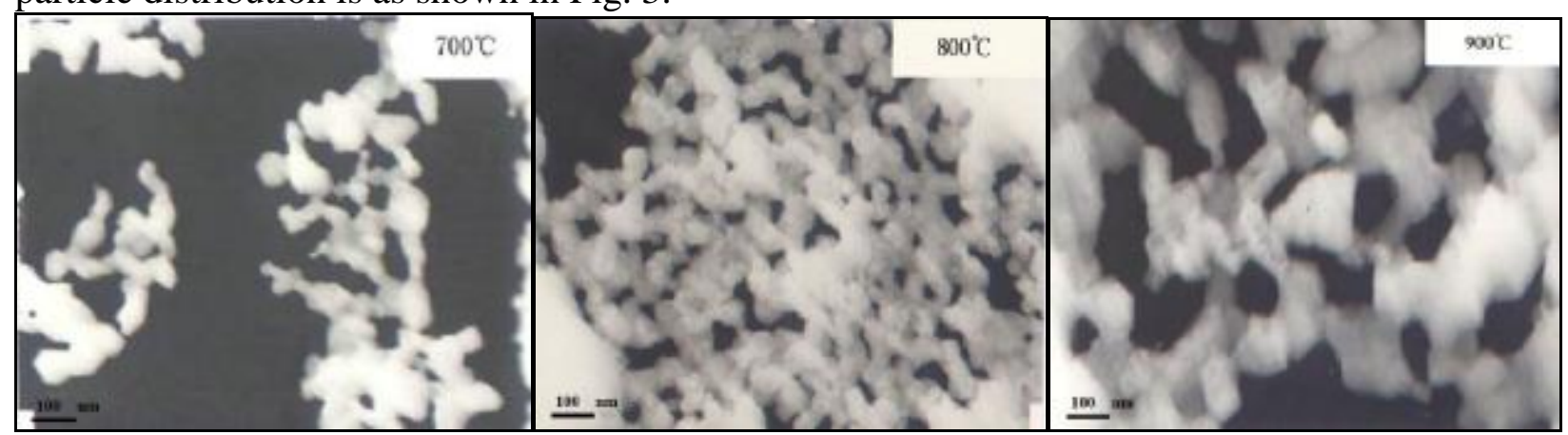

Fig. 3 TEM images of the catalyst calcined at different temperatures

(From top to bottom: $700^{\circ} \mathrm{C}, 800^{\circ} \mathrm{C}, 900^{\circ} \mathrm{C}$ )

Comparison of the above three scanning images showed that at $700{ }^{\circ} \mathrm{C}$ calcination temperature, not only is the morphology of catalyst particles irregular, but also the particles show serious agglomeration, rather than obvious dispersion. Moreover, the domain size is significantly larger than that at other temperatures, which might be attributed to the small quantity of instantaneous nucleation catalyst particles at $700{ }^{\circ} \mathrm{C}$, where the particles constantly remain in agglomeration state. In contrast, the catalyst particles dispersed uniformly at $800{ }^{\circ} \mathrm{C}$ calcination temperature, and the domain size is smaller. The potential reason is increased specific area of the catalyst due to large quantity of instantaneous nucleation catalyst particles during calcinations, and suitable particle growth rate. Since the structure has more catalytic sites, better catalysis effect could be achieved. At $900{ }^{\circ} \mathrm{C}$ calcination temperature, the domain size tends larger, even though the particle dispersion is good. Specifically, the catalyst particles dispersed uniformly due to satisfying number of instantaneous nucleation particles, however, the collision frequency increased, resulting in cohered particles and increased domain size. Thus, the catalyst specific area was decreased, affecting the catalyst effect.

Fig. 4 shows cyclic voltammograms of the gas-diffusion cathode modified with a $\mathrm{LaNi}_{1 \text { - }}$ ${ }_{\mathrm{x}} \mathrm{Co}_{\mathrm{x}} \mathrm{O}_{3}(\mathrm{x}=0,0.2,0.4,0.8,1.0)$ catalyst in $\mathrm{Na}_{2} \mathrm{SO}_{4}(0.05 \mathrm{M})$ solution at a scan rate of $10 \mathrm{mV} / \mathrm{s}$. The influence of Ni-Co ratio on the electrocatalytic performance of $\mathrm{LaNi}_{1-\mathrm{x}} \mathrm{Co}_{\mathrm{x}} \mathrm{O}_{3}$ was demonstrated. 


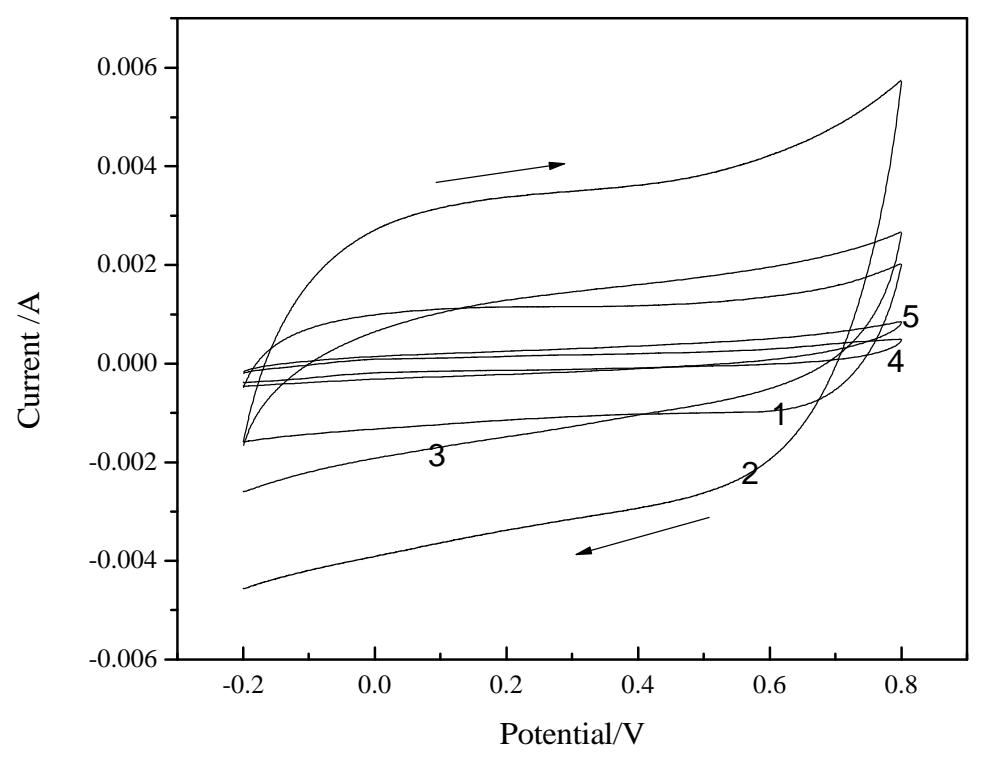

Fig. 4 cyclic voltammetry curves of different $\mathrm{Ni}-\mathrm{Co}$ ratio

$1-\mathrm{LaNiO}_{3} ; 2-\mathrm{LaNi}_{0.8} \mathrm{Co}_{0.2} \mathrm{O}_{3} ; 3-\mathrm{LaNi}_{0.6} \mathrm{Co}_{0.4} \mathrm{O}_{3} ; 4-\mathrm{LaNi}_{0.2} \mathrm{Co}_{0.8} \mathrm{O}_{3} ; 5-\mathrm{LaCoO}_{3} ;$

With increased Co doping ratio in the catalyst, the oxygen reduction current efficiency of perovskite catalyst also ascended at initial stage (1 2), indicating that Co could elevate the catalytic ability of perovskite catalyst with respect to oxygen reduction. With continuous increasing of Co doping ratio (2 5), the electrode's peak current of oxygen reduction decreased, corresponding to the reduced catalytic ability of perovskite catalyst for oxygen reduction. To be more specific, the lowest catalytic efficiency could be reached when there was no $\mathrm{Ni}$ in catalyst. Compared with other electrodes, the gas diffusion electrode (2) with mole ratio $\mathrm{Ni}: \mathrm{Co}=0.8: 0.2$ has more obvious oxygen reduction peak, and correspondingly, higher oxygen reduction current and lower voltage during oxygen reduction reaction, suggesting higher current efficiency during oxygen reduction for electrode (2), or in other words, stronger catalytic ability of the catalyst for oxygen reduction. Under the catalysis of $\mathrm{Fe}^{2+}$, more active radical $\mathrm{HO}$ - was generated. Thus, the catalyst electrode in this matching principle possesses the best degradation efficiency of wastewater. Therefore, the atomic ratio of the metals in the compound was determined to be 1:0.8:0.2(La:Ni:Co).

This is due to the fact that the catalytic ability of perovskite catalyst for oxygen reduction is related to the formation of oxygen vacancies. Crystal defects would occur at high Co doping amount, inducing varied internal structure of perovskite catalyst. Thus, the concentration of unordered oxygen vacancies in the catalyst was improved. Consequently, the ionic conductivity and active potential of the catalyst were also elevated. With continuous doping of Co element, impurity phases would increase in the catalyst, and excessive oxygen vacancies were generated, causing decreased conductivity. Hence, the catalytic activity of perovskite catalyst was affected, and the oxygen reduction current of the gas diffusion electrode became small, which will lead to descended degradation ability of the electrode for organic matters.

\section{The ultraviolet spectral analysis of thiamethoxam}

The concentration of thiamethoxam was analyzed by UV-vis spectrophotometry. The UV spectroscopy analysis of absorbance scanning curve of thiamethoxam is shown in Fig.5. The concentration of thiamethoxam is $10 \mathrm{mg} / \mathrm{L}$. Large absorption peaks were observed at $250 \mathrm{~nm}$ in the range of $190 \sim 900 \mathrm{~nm}$ wavelength and the peaks were stable at $250 \mathrm{~nm}$ before the degradation reaction. As the degradation time continues, thiamethoxam's absorption peak in the wave length of $250 \mathrm{~nm}$ becomes lower, indicating that degradation reaction can break the perssad of thiamethoxam, change its formation and turn it into other substances. There was a slight red-shift phenomenon at $200 \mathrm{~nm}$, which may be due to the effects of $\mathrm{pH}$ and polarity of the solution[31]. therefore, $250 \mathrm{~nm}$ was selected as the maximum absorption wavelength in this research. 


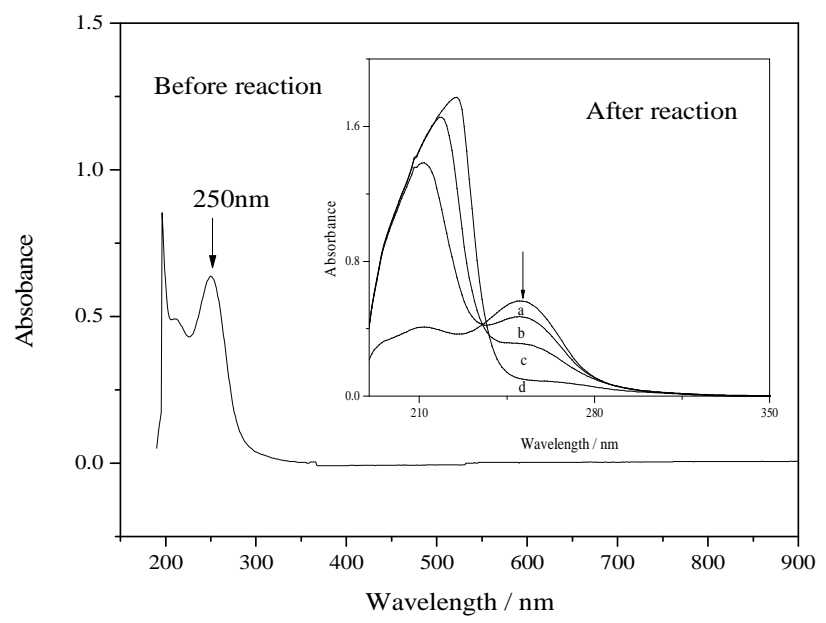

Fig. 5 Absorbance scanning curve of thiamethoxam before and after reaction.

(a:15 min; b: 30 min; c: 45 min; d:60 min)

\section{Effect of applied current density on degradation}

Applied current density has an importance influence on degradation efficiency and process economics. previous study[32] has reported that the increasing current could improve the efficiency of electrochemical oxidation process. Current densities ranging was $1.2 \sim 4.6 \mathrm{~mA} / \mathrm{cm}^{2}$. With the degradation conditions of thiamethoxam in $10 \mathrm{mg} / \mathrm{L}, \mathrm{Na}_{2} \mathrm{SO}_{4}$ in $0.05 \mathrm{M}$, pH 3 for $60 \mathrm{~min}$, the degradation efficiency of thiamethoxam as a function of current density is shown in Fig. 6. The results showed that the degradation efficiency increased as a function of applied current density, specifically, $3.1 \mathrm{~mA} / \mathrm{cm}^{2}$ current density induced maximum degradation efficiency of $82.8 \%$. A slight reduction in thiamethoxam degradation can be obtained with further increasing of current density.

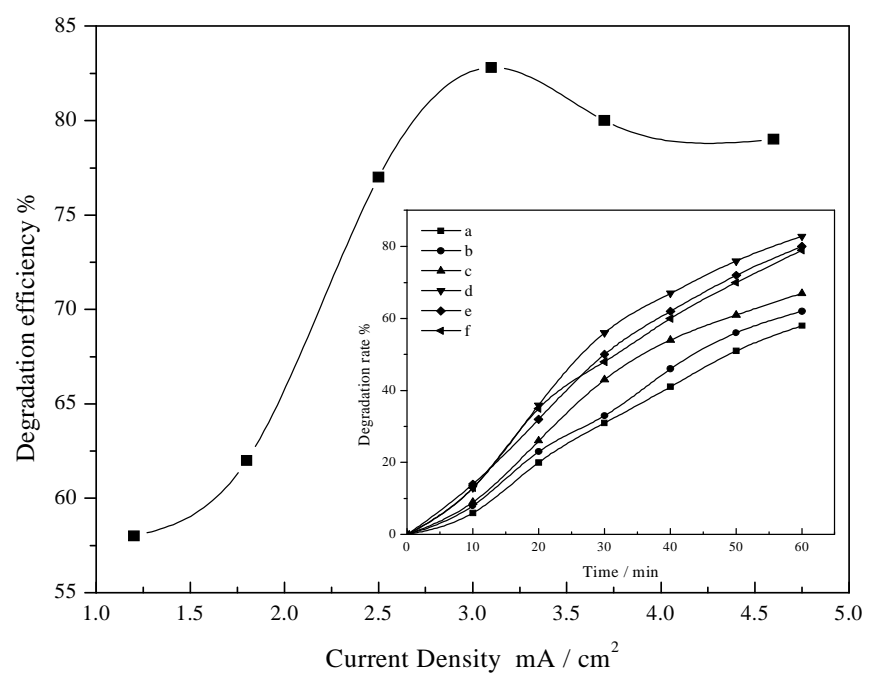

Fig. 6 Thiamethoxam degradation efficiency curve of different current densities (a:1.2 mA/cm $;$ b: $1.8 \mathrm{~mA} / \mathrm{cm}^{2} ; \mathrm{c}: 2.5 \mathrm{~mA} / \mathrm{cm}^{2} ; \mathrm{d}: 3.1 \mathrm{~mA} / \mathrm{cm}^{2} ; \mathrm{e}: 3.7 \mathrm{~mA} / \mathrm{cm}^{2} ; \mathrm{f}: 4.6 \mathrm{~mA} / \mathrm{cm}^{2}$ )

With the increasing of current density applied $\left(1.2 \sim 3.1 \mathrm{~mA} / \mathrm{cm}^{2}\right)$, the degradation efficiency also ascended. With continuous increasing current density applied $\left(3.1 \sim 4.6 \mathrm{~mA} / \mathrm{cm}^{2}\right)$, the degradation efficiency decreased instead.

At low applied current density, the voltage is not enough to participate in side reactions, which occur oxygen four-electron reduction to generate water in higher applied current density, as shown in the following reactions Eq. 5.

$$
\begin{aligned}
& \mathrm{O}_{2}+4 \mathrm{H}^{+}+4 \mathrm{e}^{-} \rightarrow 2 \mathrm{H}_{2} \mathrm{O} \\
& \mathrm{H}_{2} \mathrm{O}_{2}+2 \mathrm{H}^{+}+2 \mathrm{e}^{-} \rightarrow 2 \mathrm{H}_{2} \mathrm{O}
\end{aligned}
$$

Moreover, reduction in efficiency at high current density can be due to oxidation of $\mathrm{H}_{2} \mathrm{O}_{2}$ to 
generate water at the anode, as shown in the following reactions Eq. 6. Therefore, nearly all energy was consumed to produce $\bullet \mathrm{OH}$ for the degradation of thiamethoxam. However, the side reactions except oxygen two-electron reduction were more dominant as the current densities increased. The optimal degradation efficiency was close to approximately $79 \%$ when the current density kept at $3.1 \mathrm{~mA} / \mathrm{cm}^{2}$.

\section{Effect of $\mathrm{pH}$ value on degradation}

The solution $\mathrm{pH}$ is a chief operational parameter in the electrocatalysis oxidation process of wastewater treatment[33]. $\mathrm{pH}$ varying from 2 to 8 was investigated in $10 \mathrm{mg} / \mathrm{L}$ thiamethoxam and $0.05 \mathrm{M} \mathrm{Na}_{2} \mathrm{SO}_{4}$ at the current density of $3.1 \mathrm{~mA} / \mathrm{cm}^{2}$ for 60 minutes. The effect of $\mathrm{pH}$ on thiamethoxam degradation efficiency is presented in Fig. 7. It could be seen that the degradation efficiency increased from $\mathrm{pH} 2$ to $\mathrm{pH} 3$ and then decreased noticeably beyond $\mathrm{pH} 3$. The highest electrocatalysis activity was produced at $\mathrm{pH} 3$, where the thiamethoxam removal efficiency reached to $82.7 \%$ in 60 minutes. The optimal $\mathrm{pH}$ of EF reaction is consistent with previous study [34].

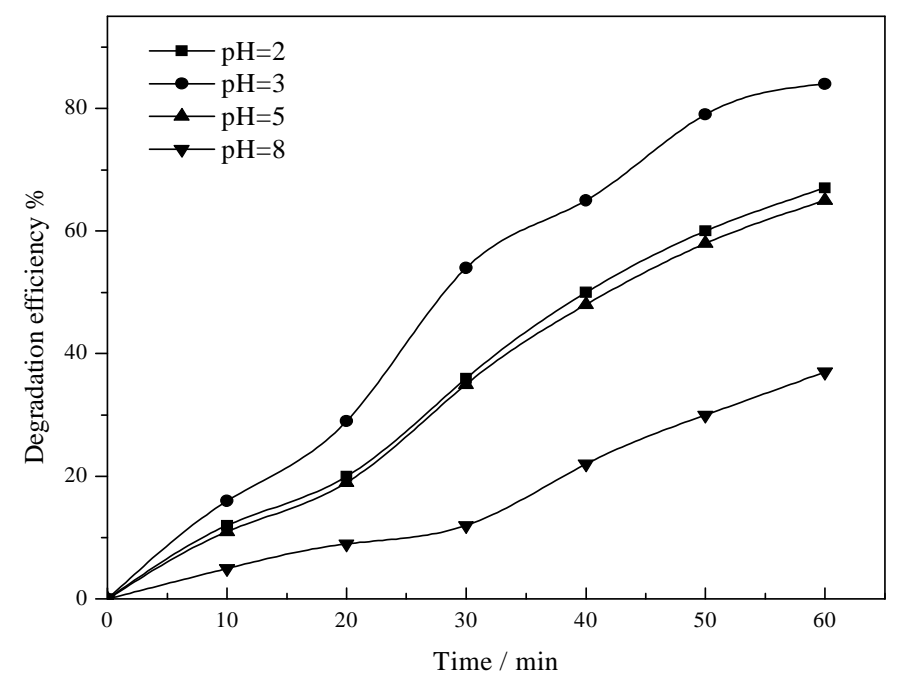

Fig. 7 Thiamethoxam degradation efficiency curve of different $\mathrm{pH}$

\section{Effect of optimal time on degradation}

Since degradation time has important implications for the degradation effect of thiamethoxam pesticide wastewater, an optimal time can lead to sufficient thiamethoxam degradation. However, it is worth noting that overlong time will result in a waste of resources, and side effects will occur, which is not conducive to electrochemistry degradation. The thiamethoxam degradation curve of different time (Fig. 8) could be obtained by studying the removal efficiency at different time of synthetic wastewater, which can contribute to the determination of suitable degradation time of thiamethoxam pesticide wastewater.

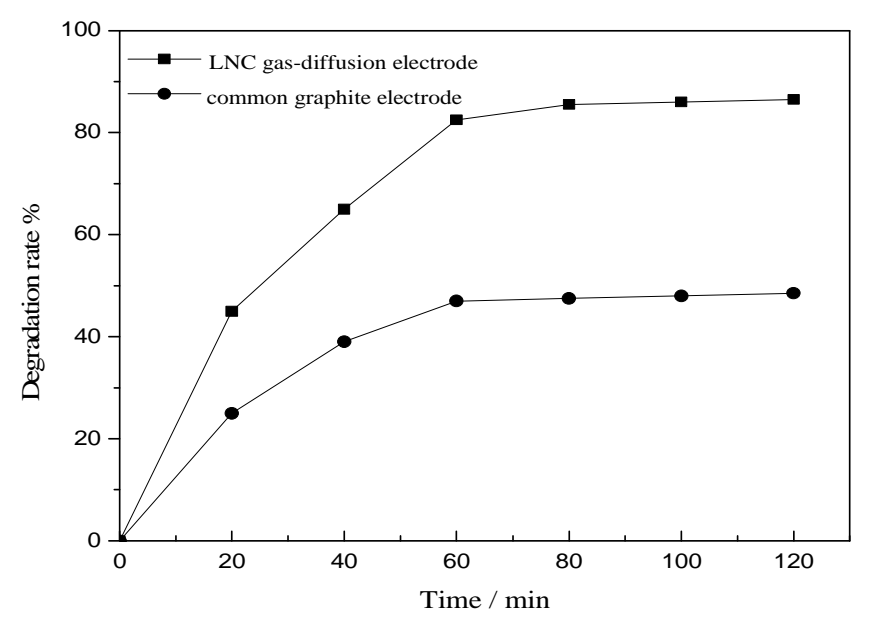

Fig. 8 Thiamethoxam degradation curve of different time

The electrocatalytic decomposition process of thiamethoxam was performed with thiamethoxam concentration of $10 \mathrm{mg} / \mathrm{L}, \mathrm{Na} 2 \mathrm{SO} 4$ of $0.05 \mathrm{~mol} / \mathrm{L}, \mathrm{pH} 3$, and current density of 3.1 
$\mathrm{mA} / \mathrm{cm} 2$. Results showed that the degradation efficiency increased as the degradation time went up to 60 minutes when maximum degradation efficiency was achieved(82.5\%). Thiamethoxam degradation can be slightly obtained with further increasing time. But the longer electrochemical degradation time is, the more energy will be consumed. The optimal electrochemical degradation time of thiamethoxam pesticide wastewater is 60 minutes. At the same time, we could also find out that the degradation efficiency of LNC gas-diffusion electrode $(82.5 \%)$ is obviously better than degradation efficiency of common graphite electrode (47\%) at 60 minutes.

\section{Determination of reaction order}

It is modeled that thiamethoxam degraded at an nth-order efficiency Eq. 7.

$-\frac{d C}{d t}=k C^{n}$

Where $\mathrm{k}$ is the apparent reaction efficiency constant, $\mathrm{C}$ is the concentration of thiamethoxam, $\mathrm{n}$ is the reaction order.

Assuming that the concentration depletion is a first-order reaction $(n=1)$, the above Eq. 7 can be described as follows Eq. 8:

$\ln \frac{C_{0}}{\mathrm{C}_{\mathrm{t}}}=\mathrm{kt}$

Where $\mathrm{C}_{0}$ and $\mathrm{C}_{\mathrm{t}}$ are the concentrations of thiamethoxam at initial time and moment $\mathrm{t}$.

Experimental study of dynamics curves (Fig. 9) and the kinetics equation (Table 4) at different current densities of thiamethoxam electrochemical degradation are shown as follows.

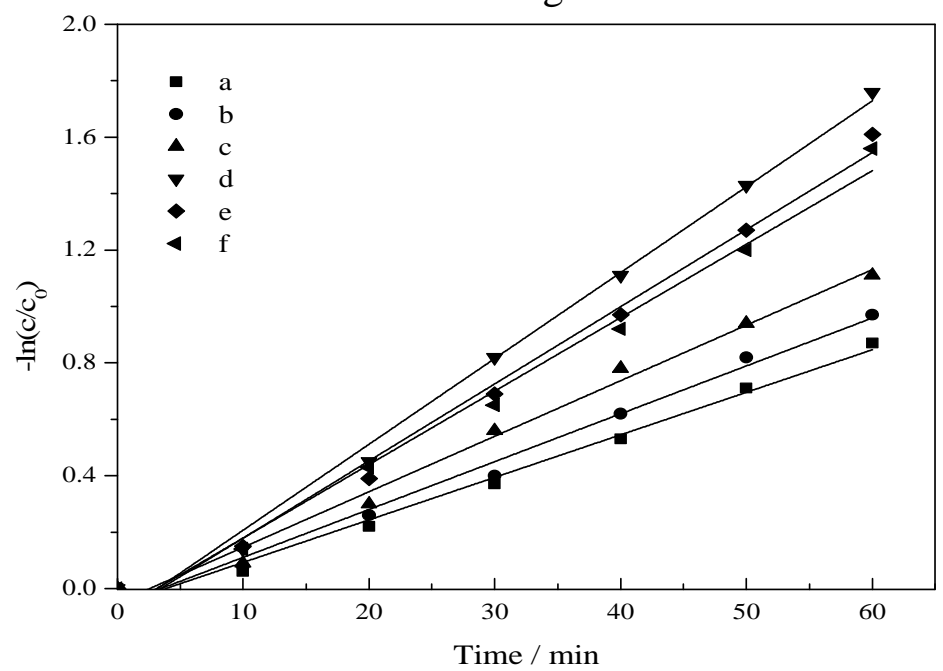

Fig. 9 Thiamethoxam degradation dynamics curves of different current densities (a: $1.2 \mathrm{~mA} / \mathrm{cm}^{2} ; \mathrm{b}: 1.8 \mathrm{~mA} / \mathrm{cm}^{2} ; \mathrm{c}: 2.5 \mathrm{~mA} / \mathrm{cm}^{2} ; \mathrm{d}: 3.1 \mathrm{~mA} / \mathrm{cm}^{2} ; \mathrm{e}: 3.7 \mathrm{~mA} / \mathrm{cm}^{2} ; \mathrm{f}: 4.6 \mathrm{~mA} / \mathrm{cm}^{2}$ )

Table 3 Thiamethoxam degradation kinetics equation of different current densities

\begin{tabular}{ccccc}
\hline No. & $\begin{array}{c}\text { Current } \\
\text { density } \\
\mathrm{mA} / \mathrm{cm}^{2}\end{array}$ & first-order kinetics reaction & $\mathrm{R}$ & $\mathrm{k}$ \\
\hline 1 & 1.2 & $-\ln \left(\mathrm{C} / \mathrm{C}_{0}\right)=0.015 \mathrm{t}-0.0561$ & 0.9901 & 0.015 \\
2 & 1.8 & $-\ln \left(\mathrm{C} / \mathrm{C}_{0}\right)=0.0169 \mathrm{t}-0.0571$ & 0.9900 & 0.0169 \\
3 & 2.5 & $-\ln \left(\mathrm{C} / \mathrm{C}_{0}\right)=0.0196 \mathrm{t}-0.0482$ & 0.9912 & 0.0196 \\
4 & 3.1 & $-\ln \left(\mathrm{C} / \mathrm{C}_{0}\right)=0.0304 \mathrm{t}-0.0981$ & 0.9926 & 0.0304 \\
5 & 3.7 & $-\ln \left(\mathrm{C} / \mathrm{C}_{0}\right)=0.0273 \mathrm{t}-0.0945$ & 0.9904 & 0.0273 \\
6 & 4.6 & $-\ln \left(\mathrm{C} / \mathrm{C}_{0}\right)=0.0261 \mathrm{t}-0.0811$ & 0.9901 & 0.0261 \\
\hline
\end{tabular}

It could be concluded from Fig. 9 and Tab. 3 that the correlation coefficient $\mathrm{R}$ for each regression equation is greater than 0.99 , and that $-\ln \left(\mathrm{C} / \mathrm{C}_{0}\right)$ is linearly correlated to t. Therefore, electrochemical degradation process of thiamethoxam pesticide wastewater at different current 
densities is consistent with first-order kinetic model. As the current density increases, the apparent reaction efficiency constant $\mathrm{k}$ firstly increases and then decreases. Specifically, the degradation efficiency of thiamethoxam constants reaches the highest value at the current density of $3.1 \mathrm{~mA} / \mathrm{cm}^{2}$.

The kinetics equation (Tab.5) at different $\mathrm{pH}$ value of thiamethoxam electrochemical degradation is shown as follows.

Tab.4 Thiamethoxam degradation kinetics equation of different $\mathrm{pH}$

\begin{tabular}{ccccc}
\hline No. & PH & first-order kinetics reaction & $\mathrm{R}$ & $\mathrm{k}$ \\
\hline 1 & 2 & $-\ln \left(\mathrm{C} / \mathrm{C}_{0}\right)=0.0192 \mathrm{t}-0.0735$ & 0.9908 & 0.0192 \\
2 & 3 & $-\ln \left(\mathrm{C} / \mathrm{C}_{0}\right)=0.0376 \mathrm{t}-0.3933$ & 0.9915 & 0.0376 \\
3 & 5 & $-\ln \left(\mathrm{C} / \mathrm{C}_{0}\right)=0.0196 \mathrm{t}-0.1311$ & 0.9908 & 0.0196 \\
4 & 8 & $-\ln \left(\mathrm{C} / \mathrm{C}_{0}\right)=0.0085 \mathrm{t}-0.0727$ & 0.9828 & 0.0085 \\
\hline
\end{tabular}

It can be seen from the charts that the correlation coefficient $\mathrm{R}$ for each regression equation is over 0.98 , suggesting that the degradation process of thiamethoxam pesticide wastewater within the studied $\mathrm{pH}$ range is in accordance with first-order kinetic model. The apparent efficiency constant $\mathrm{k}$ significantly changes, specifically, increase first and then decrease as $\mathrm{pH}$ increases, indicating that the degradation of thiamethoxam pesticide wastewater is significantly influenced by $\mathrm{pH}$ of the reaction system. The apparent efficiency constant $\mathrm{k}$ rises up to 0.0376 at $\mathrm{pH} 3$, denominating the highest thiamethoxam degradation efficiency at $\mathrm{pH} 3$.

\section{Degradation pathway and mechanism}

Processing of ion exchange column before LC-MS analysis was conducted for the thiamethoxam solution at the degradation time of $0 \mathrm{~min}, 30 \mathrm{~min}$, and $60 \mathrm{~min}$ respectively(reaction conditions: $\mathrm{pH} 3$; current density $3.1 \mathrm{~mA} / \mathrm{cm} 2$; concentration of thiamethoxam solution $10 \mathrm{mg} / \mathrm{L}$ ). The processing steps are: $100 \mathrm{ml}$ thiamethoxam solution was first extracted at time $(\mathrm{t}=0 \mathrm{~min}, 30$ $\mathrm{min}, 60 \mathrm{~min}$ ), followed by anion exchange resin of $100 \mathrm{ml}$ and cation exchange resin of $100 \mathrm{ml}$ so as to remove salts in the solution, since they do not affect the degradation of organic matter, the impact on the spectrum and instrument could be reduced.

Liquid chromatography analysis is performed with Dionex UltiMate 3000 for the LCQ Fleet. The chromatographic conditions were that regarding acetonitrile $(30 \%)$, and water $(70 \%)$ as mobile phases at the flow speed of $0.3 \mathrm{~mL} / \mathrm{min}$, and the injection volume was $20 \mu \mathrm{L}$. The LC-MS chromatograms of electrochemical degradation process about thiamethoxam solution are as follows. 
(A)

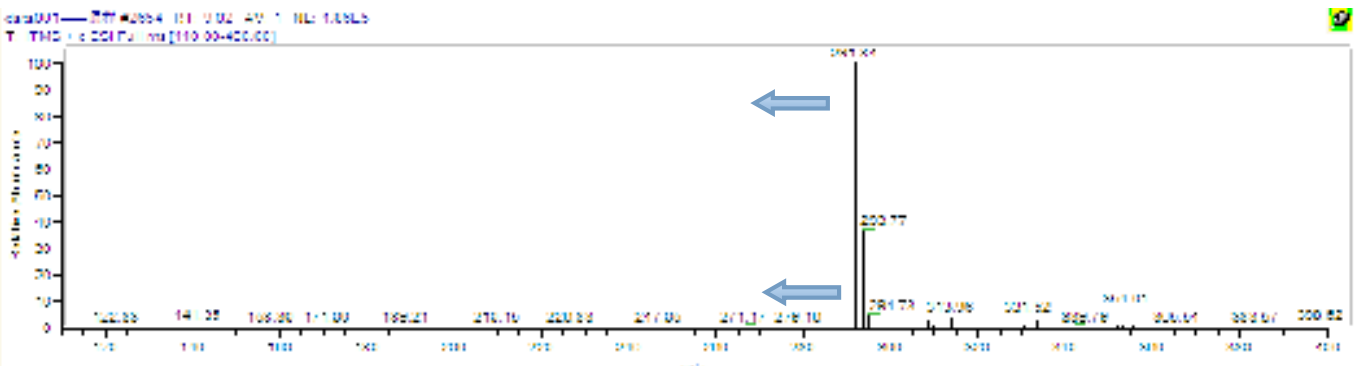

(B)

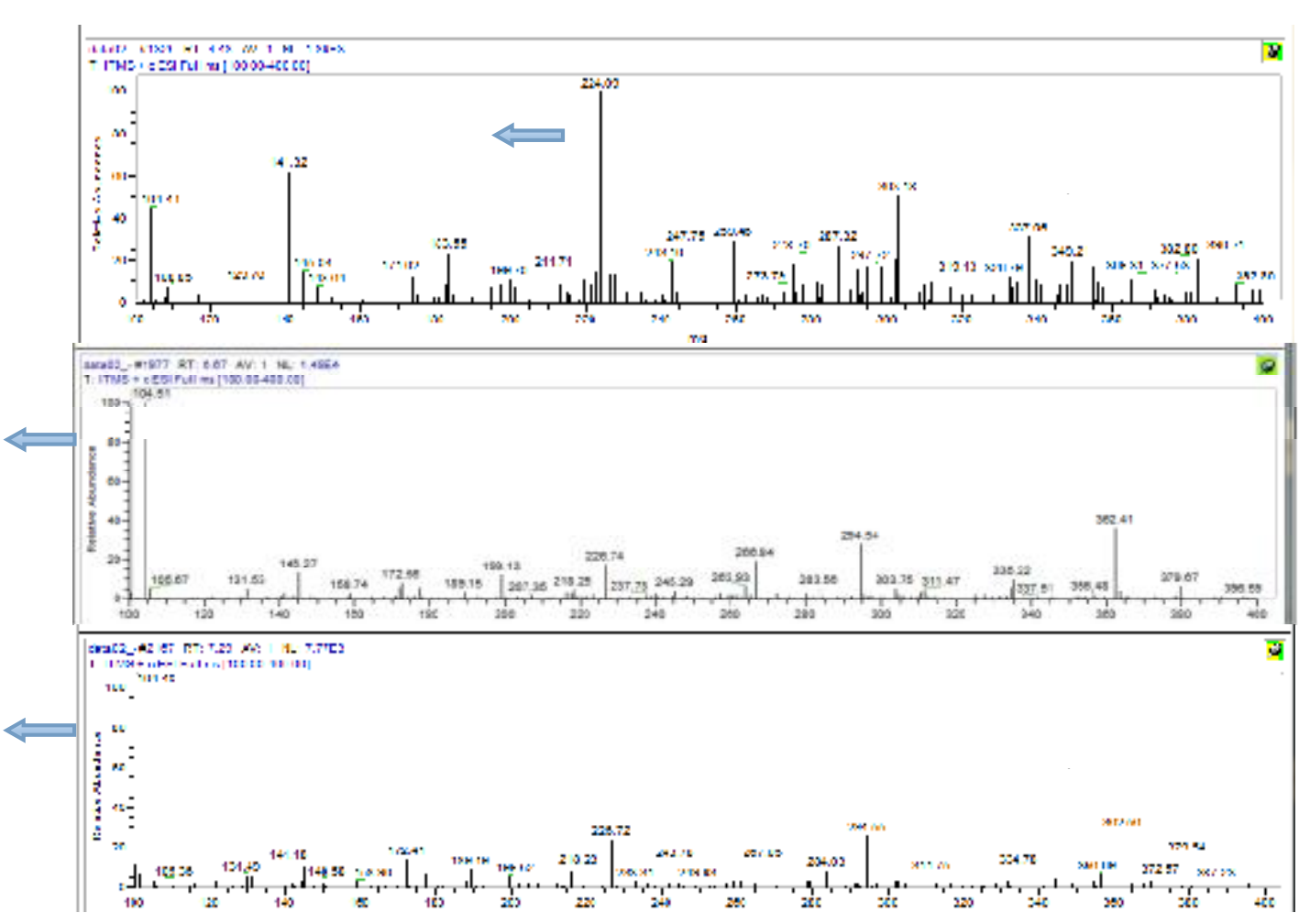

(C)

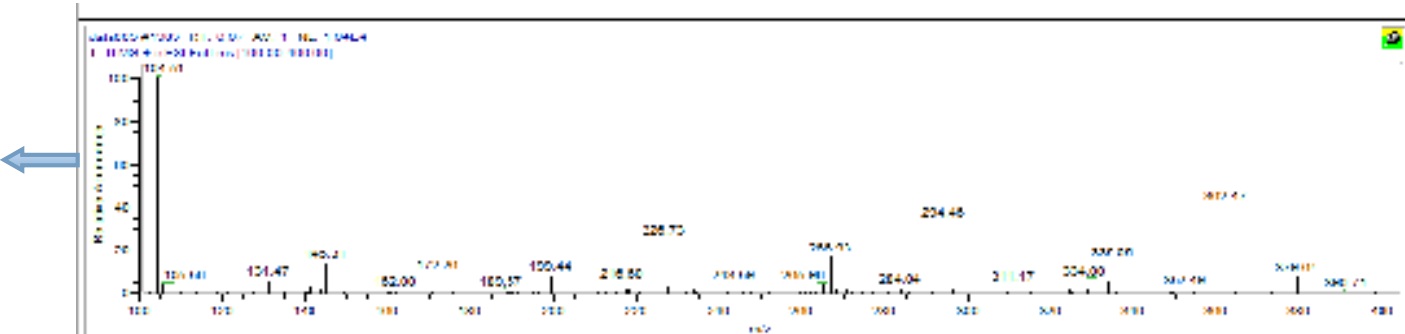

Fig. 10 (A) Ms map of thiamethoxam wastewater before treatment. (B) Ms map of intermediate a, b, c at 30 min. (C) Ms map of $83 \%$ removal efficiency of thiamethoxam at $60 \mathrm{~min}$. MS condition:(ionization mode: ESI; electrospray voltage: $3000 \mathrm{v}$; ion source temperature: $550^{\circ} \mathrm{C}$;MS range: 100 400)

An attempt was made to identify the intermediate products formed during the degradation process through mass spectrometry analysis. We can seen from the mass spectra in Fig. 11A that the relative molecular mass of 291.84, 293.77 substances of the thiamethoxam before treatment were always presented, we believed they were kinds of impurities, such as deuterium and tritium contained in the raw pesticide. the amount of thiamethoxam decreased gradually as the reaction time increased. From Fig. 11B we can see that the relative molecular mass of 224.09 (Intermediate a), 104.51(Intermediate b), 104.48(Intermediate c) substances were presented subsequently. Fig. $11 \mathrm{C}$ shows that there were few of thiamethoxam in the solution after $60 \mathrm{~min}$ of treatment. It indicated that most of thiamethoxam were decomposed into other substances. It can be concluded from Fig. 11A-C that thiamethoxam was decomposed into other new substances whose relative 
molecular masses were 224.33, 104.51 and 104.48 respectively. According to the relative molecular masses of intermediates and principles of organic degradation, the possible molecular structures of the intermediates were listed in Tab. 5.

Tab. 5 The molecular structure analysis of intermediates

\begin{tabular}{cccc}
\hline Substances & $\mathrm{m} / \mathrm{z}$ & molecular structure & Molecular formula \\
\hline Raw substance & 293.77 & 291.84 & $\mathrm{C}_{8} \mathrm{H}_{10} \mathrm{ClN}_{5} \mathrm{O}_{3} \mathrm{~S}$ \\
Intermediate a & 224.33 & & \\
Intermediate b & 104.51 & & \\
\hline
\end{tabular}

According to the structure of the degradation product of thiamethoxam, the presumed electrochemical degradation mechanism is shown in Fig. 12.

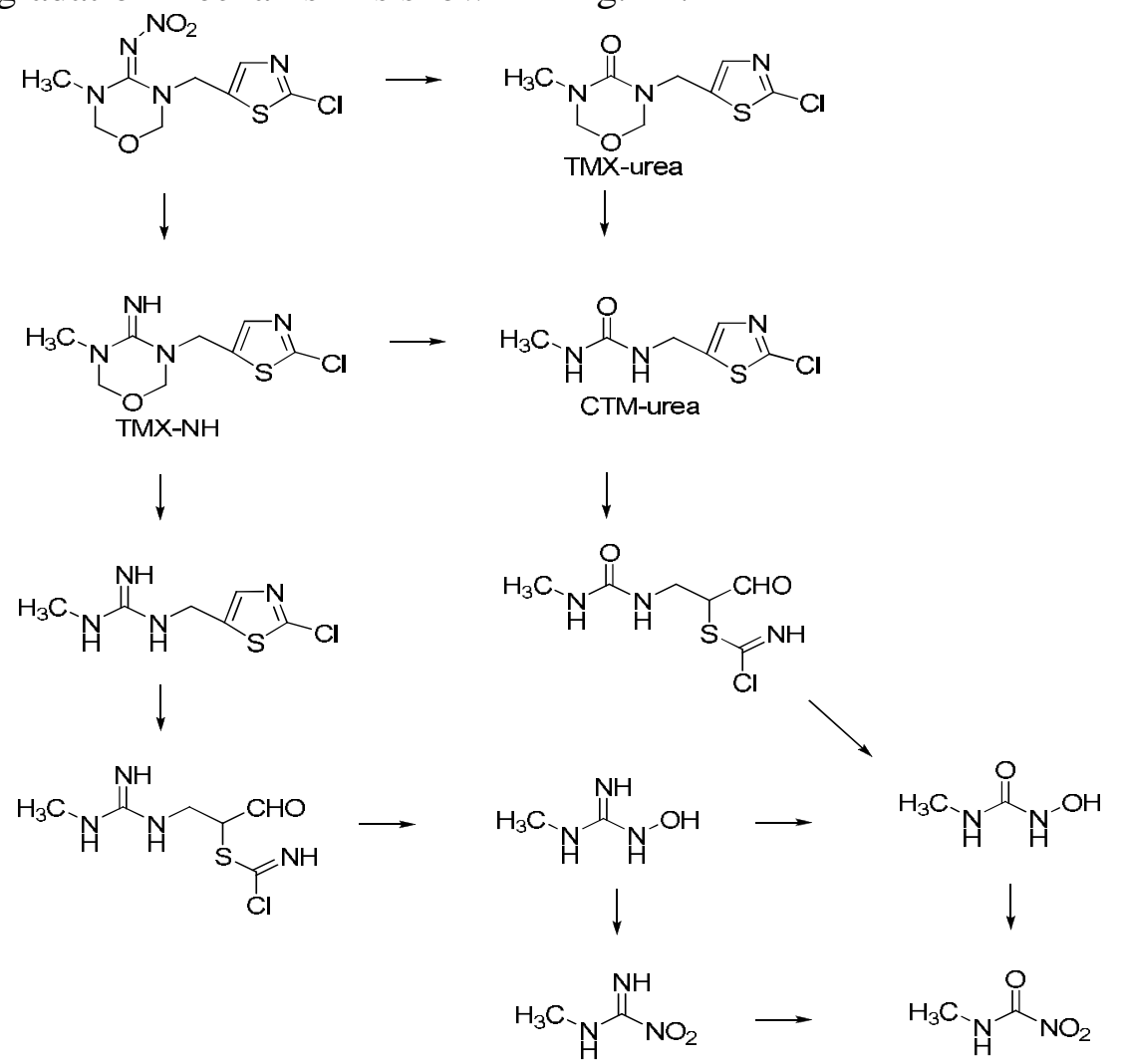

Fig. 12 Electrochemical degradation process of thiamethoxam

The electrochemical degradation process of thiamethoxam occurs in the first position of the nitro imide group because the existing lone pair of electrons in the nitrogen of $\mathrm{C}=\mathrm{N}$ group are susceptible to be attacked by HO- which has strong electron withdrawing characteristic produced by EF Oxidation Process in order to generate guanidino group $(=\mathrm{NH})$ and carbonyl group $(\mathrm{C}=\mathrm{O})$. The process is similar to that reported by Pandey[35] etc, where bacterial degradation method was used to deal with thiamethoxam to generate the final products including TMX-NH and TMX-urea. In addition, J.Schwartz[36] reported that light degradation products mainly include CTM-urea. However, the electrochemical degradation process of thiamethoxam is more thoroughgoing. Specifically, TMX-NH and TMX-urea would continue to experience bond cleavage reaction, 
thereby generating $\mathrm{N}$-methyl-nitro-formamide, as well as inorganic small molecular $\mathrm{CO}_{2}, \mathrm{H}_{2} \mathrm{O}, \mathrm{Cl}^{-}$, $\mathrm{SO}_{4}{ }^{2+}, \mathrm{NH}_{4}{ }^{+}, \mathrm{NO}_{3}{ }^{-}$etc.

\section{Conclusions}

Using $\mathrm{LaNi}_{0.8} \mathrm{Co}_{0.2} \mathrm{O}_{3}$ as a gas diffusion electrode catalyst demonstrated good electro-catalysis performance for the degradation of thiamethoxam pesticide wastewater. The removal efficiency of thiamethoxam pesticide wastewater reached $82.5 \%$ after 60 minutes electrolysis for synthetic wastewater containing $10 \mathrm{mg} / \mathrm{L}$ thiamethoxam and $0.05 \mathrm{M} \mathrm{Na}_{2} \mathrm{SO}_{4}$ supporting electrolyte at the current density of $3.1 \mathrm{~mA} / \mathrm{cm}^{2}$, and $\mathrm{pH} 3$, which obviously higher than commom graphite electrode $(47 \%)$. The kinetics of thiamethoxam degradation was in accordance with the first order reaction kinetics within the scope of the investigated current densities and $\mathrm{pH}$. Based on the experimental analysis, the degradation mechanism involved the attack of $\mathrm{HO} \cdot$ produced by EF Oxidation Process, $\mathrm{N}$-methyl-nitro-formamide was identified as the main intermediate product with continuously oxidized $\mathrm{C}=\mathrm{N}$ ring cleavage, ultimately leading to the transformation of thiamethoxam to ringopening products and to small inorganic molecules.

\section{Acknowledgements}

This research was supported by the Technological Progress Plan of Shandong, Grant No. 2011GGE27048, China. The authors are grateful to the anonymous reviewers for their reading of the manuscript, and for their suggestions and critical comments.

\section{References}

[1]Maienfisch, P., Angst, M., Brandl, F., Fischer, W., D.Hofer, Kayser, H., Kobel, W., Rindlisbacher, A., Senn, R., Steinemann, A., Widmer, H., Chemistry and biology of thiamethoxam: A second generation neonicotinoid, Pest Manag. Sci. (2001), 57 , 906-913.

[2] de Urzedo, A.P.F.M., Diniz, M.E.R., Nascentes, C.C., Catharino, R.R., Eberlin, M.N., Augusti, R., Photolytic degradation of the insecticide thiamethoxam in aqueous medium monitored by direct infusion electrospray ionization mass spectrometry, J. Mass Spectrom. (2007), 42, 13191325.

[3]Puinean, A.M., Denholm, I., Millar, N.S., Nauen, R., Williamson, M. S., Characterisation of imidacloprid resistance mechanisms in the brown planthopper, Pestic. Biochem. Phys. (2010), 97, 129-132.

[4]Ram, S.D., Lal, O.P., Bio-efficacy of thiamethoxam in comparison to recommended insecticides against leafhopper and white fly of brinjal (Solanum melongena L.), J. Entomol. Res. (2002), 26, 257-262.

[5]Misra, H.P., Senapati, B., Evaluation of new insecticides against okra jassid (Amrasca biguttula), Indian J. Agric. Sci. (2003), 73, 576-578

[6]Saien, J., Khezrianjoo, S., Degradation of the fungicide carbendazim in aqueous solutions with $\mathrm{UV} / \mathrm{TiO}_{2}$ process: Optimization, kinetics and toxicity studies, J. Hazard. Mater. (2008), 157, 269-276.

[7]Saien, J., Soleymani, A.R., Degradation and mineralization of Direct Blue 71 in a circulating upflow reactor by $\mathrm{UV} / \mathrm{TiO}_{2}$ process and employing a new method in kinetic study, J. Hazard. Mater. (2007), 144, 506-512.

[8]Zhao, J.Y., Zhang, Y. B., Quan, X., Chen, S., Enhanced oxidation of 4-chlorophenol using sulfate radicals generated from zero-valent iron and peroxydisulfate at ambient temperature, Sep. Purif. Technol. (2010), 71, 302-307.

[9] Gu, J.J., Wang, Z., Fan, Z.F., Xie, L.X., Liu, G.C., Wang, S.C., Chemical Oxidation Technology in Treatment of Pharmaceutical Wastewater Containing Antibiotic, Chem. Ind. Chem. Q. (2007), 4, 291-313.

[10]Oller, I., Malato, S., Sánchez-Pérez, J.A., Combination of Advanced Oxidation Processes and 
biological treatments for wastewater decontamination, Sci. Total. Environ. (2011), 409, 41414166.

[11] Yang, S., Jiang, J., Zhang, Y.Q., Applications Development of Wet Oridation, Environ. Sci. MGT. (2005), 4, 88-98.

[12]Chang, S.J., Liu, Y.C., Degradation mechanism of 2,4,6-trinitrotoluene in supercritical water oxidation, J. Environ. Sci. (2007), 19, 1430-1435.

[13] Wang, H., Wang, J.L., Electrochemical degradation of 4-chlorophenol using a novel Pd/C gasdiffusion electrode, Appl. Catal. B: Environ. (2007), 77, 58-65.

[14]Moradi, M., Ghanbari, F., Application of response surface method for coagulation process in leachate treatment as pretreatment for Fenton process: Biodegradability improvement, J. Water Process Eng. (2014), 4, 67-73.

[15] Hui Zhang, Chengzhi Fei, Daobin Zhang, Feng Tang.Degradation of 4-nitrophenol in aqueous medium by electro-Fenton method.(2007), 145(1-2):227-232..

[16] P. Ciambelli, S. Cimino, L. Lisi, M. Faticanti, G. Minelli, I. Pettiti, P. Porta.La, Ca and Fe oxide perovskites: preparation, characterization and catalytic properties for methane combustion. Applied Catalysis B:Environmental.(2001), 33(3):193-203.

[17] Alifanti, M., Kirchnerova, J., Delmon, B., Klvana, D., Methane and propane combustion over lanthanum transition-metal perovskites: role of oxygen mobility, Appl. Catal. A: Gen. (2004), $262,167-176$.

[18]Bursell, M., Pirjamali, M., Kiros, Y., $\mathrm{La}_{0.6} \mathrm{Ca}_{0.4} \mathrm{CoO}_{3}, \quad \mathrm{La}_{0.1} \mathrm{Ca}_{0.9} \mathrm{MnO}_{3}$ and $\mathrm{LaNiO}_{3}$ as bifunctional oxygen electrodes, Electrochim. Acta. (2002), 47 , 1651-1660.

[19]Silva, R.A., Soares, C.O., Carvalho, M.D., Rangel, C.M., da Silva Pereira M. I., Stability of $\mathrm{LaNiO}_{3}$ gas diffusion oxygen electrodes, J. Solid State Electrochem. (2014), 18, 821-831.

[20]Rida, K., Pena, M.A., Sastre, E., Martinez-Arias, A., Effect of calcination temperature on structural properties and catalytic activity in oxidation reactions of $\mathrm{LaNiO}_{3}$ perovskite prepared by Pechini method, J. Rare Earth, (2012), 30, 210-216

[21]An, J., Zhu, L., Wang, N., Song, Z., Yang, Z., Du, D., Tang, H., Photo-Fenton like degradation of tetrabromobisphenol A with graphene $\mathrm{ABiFeO}_{3}$ composite as a catalyst, Chem. Eng. J., (2013), 219, 225-237.

[22]Wang, F.Z., Yan, D., Zhang, W.Y., Chi, B., Pu, J., Jian, L., $\mathrm{LaCo}_{0.6} \mathrm{Ni}_{0.4} \mathrm{O}_{3-\delta}$ as cathode contact material for intermediate temperature solid oxide fuel cells, Int. J. Hydrogen Energy, (2013), 38, 646-651.

[23]Pakhare, D., Haynes, D., Shekhawat, D., Role of metal substitution in lanthanum zirconate pyrochlores $\left(\mathrm{La}_{2} \mathrm{Zr}_{2} \mathrm{O}_{7}\right)$ for dry $\left(\mathrm{CO}_{2}\right)$ reforming of methane (DRM), Appl. Petrochem. Res. (2012), 2, 27-35.

[24]Boreave, A., Tan, H. L., Roche, V., Vernoux, P., Deloume, J-P., Oxygen mobility in lanthanum nickelate catalysts for deep oxidation of propane, Solid State Ionics, (2008), 179, 1071-1075.

[25]Li, S.P., Lian,J.F., Cao, H.L., Self-made gas diffusion electrodes for dye wastewater treatment, Adv. Mater. Res. (2011), 152-153, 1704-1711.

[26]Duesterberg, C.K., Waite, T. D., Process optimization of fenton oxidation using kinetic modeling, Environ. Sci. Technol. (2006), 40, 4189-4195.

[27]Jara-Palacios, M.J., Hernanz, D., Escudero-Gilete, M.L., Heredia, F. J., Antioxidant potential of white grape pomaces: Phenolic composition and antioxidant capacity measured by spectrophotometric and cyclic voltammetry methods, Food Res. Int. (2014), 66, 150-157.

[28] Rida K, Benabbas A, Bouremmad F, et al. Effect of calcination temperature on the structural characteristics and catalytic activity for propene combustion of sol-gel derived lanthanum chromite perovskite[J]. Applied Catalysis A: General, (2007), 327(2): 173-179.

[29] Duran P, Tartaj J, Capel F, et al. Formation, sintering and thermal expansion behaviour of Srand $\mathrm{Mg}$-doped $\mathrm{LaCrO} 3$ as SOFC interconnector prepared by the ethylene glycol polymerized complex solution synthesis method[J]. Journal of the European Ceramic Society, (2004), 24(9): 2619-2629.

[30]Liu, G., Li, J.Q., Yang, K., Tang, W.X., Liu, H.D., Yang, J., Yue, R.L., Chen, Y. F., Effects of 
cerium incorporation on the catalytic oxidation of benzene over flamemade perovskite $\mathrm{La}_{1-\mathrm{x}} \mathrm{Ce}_{\mathrm{x}} \mathrm{MnO}_{3}$ catalysts, Particuology, In Press, Corrected Proof, Available online. (2014)

[31] Khan, A., Haque, M.M., Mir, N.A., Muneer, M., Heterogeneous photocatalysed degradation of an insecticide derivative acetamiprid in aqueous suspensions of semiconductor, Desalination, (2010), 261, 169-174.

[32]Bejankiwar, R., Lalman, J.A., Seth, R., Electrochemical degradation of 1,2-dichloroethane (DCA) in a synthetic groundwater medium using stainless-steel electrodes, Water Res. (2005), 39, 4715-4724.

[33]Zhou, M.H., Yu, Q.H., Lei, L.C., Electro-Fenton method for the removal of methyl red in an efficient electrochemical system, Sep. Purif. Technol. (2007), 57, 380-387.

[34]Suárez-Alcántara, K., Rodríguez-Castellanos, A., Dante, R., $\mathrm{Ru}_{\mathrm{x}} \mathrm{Cr}_{\mathrm{y}} \mathrm{Se}_{\mathrm{z}}$ electrocatalyst for oxygen reduction in a polymer electrolyte membrane fuel cell, J. Power Sources, (2006), 157, 114-120.

[35]Pandey, G., Dorrian, S.J., Russell, R.J., Oakeshott, J.G., Biotransformation of the neonicotinoid insecticides imidacloprid and thiamethoxam by Pseudomonas sp. 1G, Biochem. Bioph. Res. Co. (2009), 380, 710-714.

[36]Schwartz, B.J., Sparrow, F.K., Heard, N.E., Thede, B.M., Simultaneous Derivatization and Trapping of Volatile Products from Aqueous Photolysis of Thiamethoxam Insecticide, J. Agr. Food Chem. (2000), 48, 4671-4675. 